\title{
Place of Infrastructure in the Innovation Ecosystem of Industry
}

\author{
Artur D. Bobryshev ${ }^{1 *[O R C I D ~ 0000-0003-1575-5361], ~}$ \\ Valeriy M. Tumin 2[ORCID 0000-0003-4651-0359], \\ Andrei V. Savelyev 1[ORCID 0000-0002-7438-4698], \\ Elena E. Alenina 2[ORCID 0000-0002-0109-3064], \\ Vladimir A. Trifonov 3[ORCID 0000-0003-2815-3749]
}

\author{
I Federal State Unitary Enterprise “All-Russia Scientific and Research Institute “Center”, Moscow, Russia \\ ${ }^{2}$ Moscow Polytechnic University, Moscow, Russia \\ ${ }^{3}$ Yaroslav-the-Wise Novgorod State University, Veliky Novgorod, Russia \\ 3646410@mail.ru
}

\begin{abstract}
An analysis of the reasons for the low innovation activity of domestic industrial enterprises indicates that one of the significant circumstances that keep constraining the mastering of new equipment, technologies, organizational and marketing decisions is the insufficient level of development of the innovation infrastructure, the formation of new elements of which began in the mid-nineties of the last century. At the same time, both among domestic researchers and foreign specialists in innovation, there is no unambiguous understanding of this category, which does not allow us to reasonably offer a set of organizational and economic tools to compensate for this deficiency. The goal of this paper is to concretize the concept of innovation infrastructure in order to correctly determine the ways of its development to a level capable of removing obstacles to the accelerated mastering of innovations in production. In the course of achieving the goal, the challenges of identifying the significance of the studied category in innovation development, of concretizing the concept of innovation infrastructure in accordance with the logic dictated by the classification of types of economic activity, as well as of substantiating the methods that should be used when solving issues of its development have been met. The results allow us to assert that innovation infrastructure belongs to the sphere of economic activities, the purpose of which is not to generate new knowledge or to replicate new products, but to serve the processes of creating and mastering innovations in industry. This conclusion determines the methods which should be applied in the development of innovation infrastructure, in particular, the methods of organizing economic networks and clusters. Their main distinguishing feature is their applicability not to the production sphere, but to the sphere of scientific services in the terminology that was used to qualify the branches of the national economy of Russia.
\end{abstract}

Keywords: innovation, infrastructure, industry, ecosystem, optimization methods

\section{INTRODUCTION}

The current system of organizing the scientific and technological development of industry in Russia (innovation ecosystem) does not yet allow us to recognize it as appropriate to its intended purpose which is to ensure the large-scale creation and mastering of production of new equipment and technologies, the introduction of modern organizational and marketing solutions.
This is evidenced by the data of domestic statistics and international comparisons. For example, in the Russian industry over the past 10 years of statistical observations, the share of innovative goods, work, services in the total volume of goods in transit, work and services performed have not risen above $8.9 \%$, averaging $7.1 \%$ (Figure 1). At the same time, in the European countries leading in innovative development, this indicator has been at the level from 20 to more than $40 \%$ [1]. In 
terms of the level of innovation activity, Russian industrial enterprises are also significantly inferior to European ones. In 2018, the value of this indicator for the Russian industry reached $15.6 \%$ [2] versus $40-60 \%$ in the leading European countries [1].

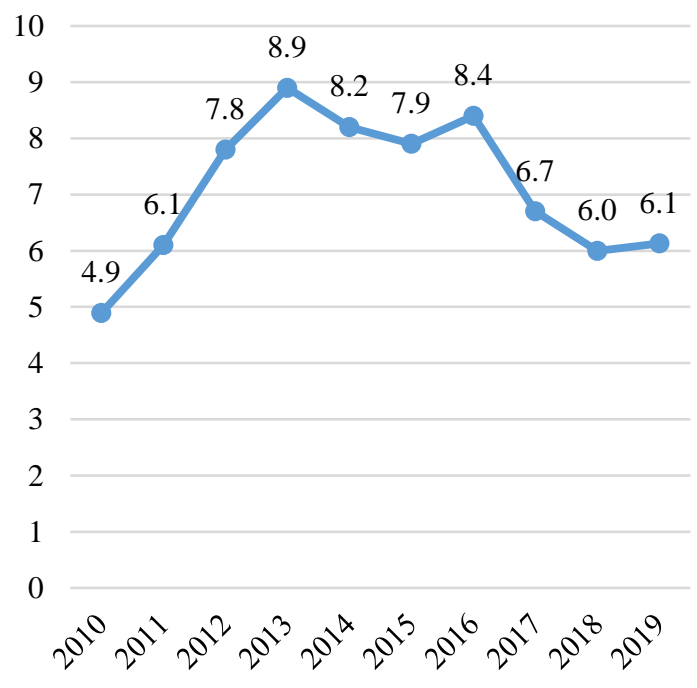

Figure 1. The share of innovative goods, work, services in the total volume of goods in transit, work and services performed in industry

Source: [3]

Innovation studies researchers give a number of reasons explaining this state of affairs: from trivial, obvious to complex ones hidden in related areas of knowledge [4-7]. One of the widespread opinions is the lack of funds to create and master new equipment and other innovations. This point of view is shared by many respected scientists. At the same time, not limiting themselves to stating this simple idea, they pose the problem more broadly, linking our failures in the field of innovation with the consequences of the wrong course of reforms chosen in the 1990s in the context of the so-called
Washington Consensus, which, among other things, explains Russia's dependence on energy exports instead of full-fledged sovereign scientific and technological development. The result of this course was the aging of the productive facilities, the growth of dependence on imports, the decline in the competitiveness of the products of the Russian industry, the degradation of scientific and technical potential, and, as a consequence, a low level of innovation activity.

N.I. Komkov, Head of the Laboratory of the Institute of Economic Forecasting of the Russian Academy of Sciences, and his colleagues present their vision of the structure of factors hindering innovation [8]. Along with the problems already mentioned, the authors point to the insufficient level of innovation infrastructure development. One of the successful definitions of this concept is given in D.I. Kokurin and K.N. Nazin's work: "Innovation infrastructure is a complex of organizational and economic institutions that directly ensure conditions for the implementation of innovative processes by economic entities (including specialized innovative organizations) based on the principles of economic efficiency of both the national economy as a whole and its economic entities in the conditions of market fluctuations" [9].

Their opinion and the significance of this problem are being developed by such scientists as A.V. Raikhlina, who has offered her view on the development of this category [10]; T.V. Eferina and her colleagues, who have pointed out the unevenness of the geographic distribution of innovation infrastructure elements [11] (Table 1); I.G. Dezhina, who have distinguished the importance of certification and technical regulation to ensure the international competitiveness of domestic innovative products [12].

Table 1. Distribution of innovation infrastructure elements across the territory of the Russian Federation, 2016

\begin{tabular}{|l|c|c|}
\multicolumn{1}{|c|}{ Federal District } & \multicolumn{2}{c|}{ Number of Innovation Infrastructure Elements } \\
\cline { 2 - 3 } & \multicolumn{1}{c|}{ units } \\
\hline Central Federal District & 548 & $32.4 \%$ \\
\hline Volga (Privolzhsky) Federal District & 362 & $21.4 \%$ \\
\hline Siberian Federal District & 289 & $17.1 \%$ \\
\hline Northwestern Federal District & 155 & $9.2 \%$ \\
\hline Southern Federal District & 138 & $8.2 \%$ \\
\hline Ural Federal District & 88 & $5.2 \%$ \\
\hline Far Eastern Federal District & 54 & $3.2 \%$ \\
\hline North Caucasian Federal District & 50 & $3.0 \%$ \\
\hline Crimean Federal District & 9 & $0.5 \%$ \\
\hline Total & 1693 & $100 \%$ \\
\hline
\end{tabular}

Source: Calculated by the authors according to [11]

If the research results of Russian scientists demonstrate that only $3.1 \%$ of specialists pay attention to the underdevelopment of the innovation infrastructure [8], then foreign innovation 
researchers take a completely different view. For example, the results of determining the global innovation index (GII) [13] in 2020 showed that the low level of infrastructure development is the second most important factor determining Russia's low position in this authoritative international ranking (Figure 2).

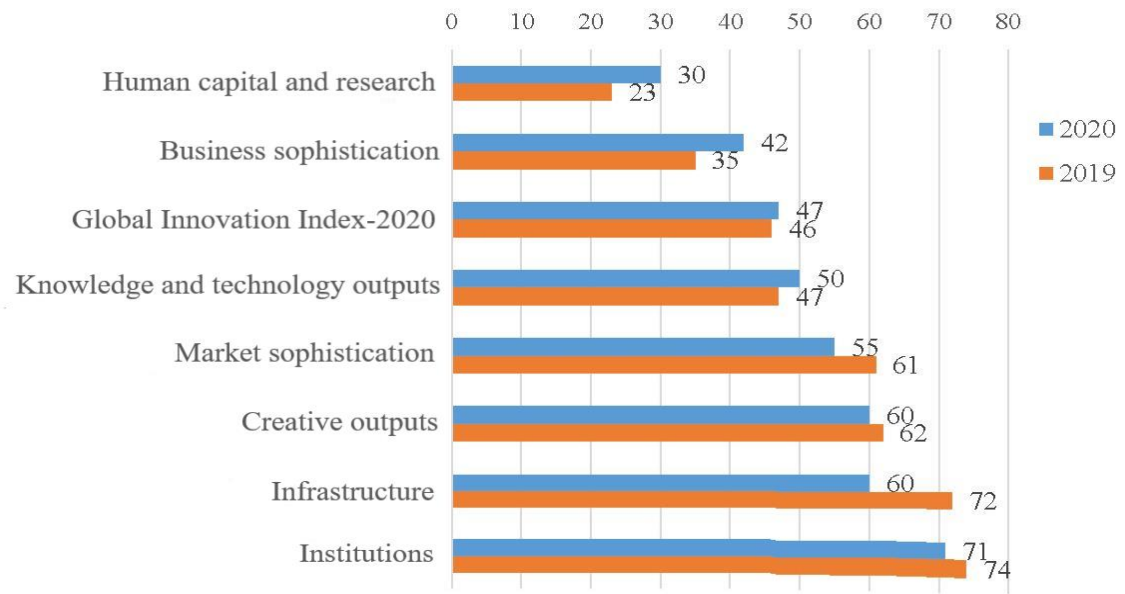

Figure 2. Russia's positions in the GII-2019 and GII-2020 rankings by index elements [13] Source: [13]

As follows from the above data, despite the fact that in 2020 Russia was in 47 th position out of 131 possible in the GII as a whole, its position in terms of infrastructure development turned out to be much worse -60 th.

\section{MATERIALS AND METHODS}

When conducting the study, the authors set themselves the goal, based on international comparisons, to analyze differences between types of economic activity, as well as semantic features, in order to concretize the concept of innovation infrastructure and to correctly determine the ways of its development to a level capable of removing obstacles to the accelerated mastering of innovations in Russian industry.

In the course of achieving the goal, the challenges of identifying the significance of the category under study in the organization of innovative development, of specifying the concept of innovation infrastructure in accordance with the logic dictated by the classification of economic activities, as well as of substantiating the methods that should be used in solving issues of its development have been met.

\section{RESULTS}

Without denying the general expediency of international comparisons, it should be assumed that this difference in estimates is largely caused by a different understanding of the category of "innovation infrastructure" in our country and abroad. When calculating the GII, the following content of this category is used (Figure 3).

From the analysis of the composition of the indicators characterizing the "infrastructure" indicator, it becomes clear that, with the exception of the first two parameters of sub-indicator 3.1, the remaining indicators bear no relation to the concept of "innovation infrastructure" in the sense that is embedded in Russian legislation considering innovation infrastructure as a set of entities that assist in the implementation of innovation projects in terms of management, logistics, information, financial and other services.

An expansive interpretation of the concept of infrastructure is generally characteristic of foreign researchers. This is obviously due to their accepted global understanding of this category, which is based on a common term Infrastructure (from Latin Infra - below and struktura - structure) and represent a complex of interconnected service structures that make up and/or provide a basis for meeting challenges [14].

For example, well-known business modeling specialists A. Osterwalder and Y. Pigneur refer key business partners, the actions necessary for the functioning of the business, as well as resources for creating and delivering the product to consumers to the infrastructure of an industrial enterprise [15]. In contrast to them, for example, in domestic practice, the industrial infrastructure and the infrastructure of industrial activity support are dismantled. 


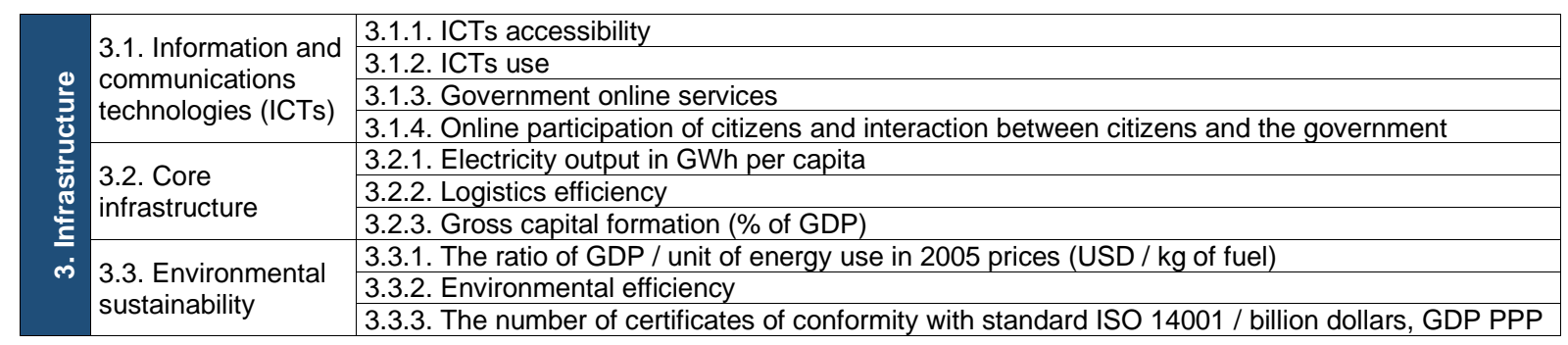

Figure 3. The content of the "infrastructure" indicator in the GII calculation methodology Source: [13]

Therefore, it is useful to focus on international comparisons and opinions of foreign economists and clearly understand their political bias and the difference between the views of domestic and foreign specialists in innovation in relation to the terminology used. In general, in world practice, the term "innovation infrastructure" is not used as an independent one. Foreign experts distinguish not infrastructure entities, but "services" for startups and innovative companies as integral elements of the innovation ecosystem [16].

It should be noted that in domestic practice, confusion of concepts in the characteristics of the categories under study is frequently allowed. In particular, there is an opinion that the innovation infrastructure includes research institutes engaged in the "generation of ideas" and industrial enterprises whose tasks include "production and sale of products". In this case, it becomes unclear what is the difference between innovation infrastructure entities and other participants in the process of creating, mastering, and producing new equipment.

Attention is drawn to the fact that the above opinion of Russian researchers does not contradict the provisions of the authoritative international publication on the measurement of innovations - the Oslo Manual which also broadly interprets the concept of infrastructure. Article 149 of this document states that "Innovative activities are all scientific, technological, organizational, financial and commercial actions that actually lead to the implementation of innovations or conceived for this purpose. Some types of innovative activity are innovative in themselves, others do not have this property, but are also necessary for the implementation of innovations. The innovative activity also includes research and development not directly related to the preparation of any particular innovation" [17]. From this definition, the difference in the tasks and functions of the main participants in the innovation process and those structures that assist them is not clear. Although it is quite obvious that, for example, the activities of an industrial enterprise and a business incubator have completely different goals, objectives, technologies, organization, personnel, and logistical support.

It seems that when distinguishing between the main participants in the innovation process and the infrastructure that ensures their activity in creating and mastering the production of innovations, one should be guided by the following provision of the Oslo Manual which is as follows: "A common feature of innovation is that it should be implemented. A new or improved product is implemented when it is put on the market. New production processes, marketing methods or organizational methods are implemented when they have come to be really used in a company's activities" [17].

In modern Russian science, the term "commercialization" is synonymous with the concept of implementation. The long-term practice of scientific and technical activity in the Soviet Union and in modern Russia has repeatedly proved that no matter what magnificent developments are generated by our science, their development in practice, as a rule, either turns out to be not in demand, or occurs slowly, or at a limited number of enterprises, or even abroad. On the other hand, in conditions of a high degree of monopolization of Russian industry and limited domestic demand, enterprises are not often in urgent need of innovations that require additional costs and actions, opportunities, skills, and specialists which they do not always have. Innovation infrastructure companies are called upon to compensate for such a deficit.

Thus, the main distinguishing feature of the intended purpose of the innovation infrastructure is the creation of conditions for the elimination of these contradictions by performing the functions of innovative intermediaries by its entities on various aspects of the process of introducing new equipment, technologies, organizational and marketing solutions. 
Despite the wide range of opinions, there are examples of a fairly clear, free from the noted misconceptions understanding of the content of the category "innovation infrastructure" in the domestic scientific literature [10]. According to Scientific Research Institute - Federal Research Centre for
Projects Evaluation and Consulting Services (hereinafter - SRI FRCEC), quantitative data on the elements of the innovation infrastructure (in their limited number) as of August 2021 is presented in Table 2.

Table 2. Elements of the innovation infrastructure of the Russian Federation in the interpretation of SRI FRCEC, units

\begin{tabular}{|l|c|}
\hline \multicolumn{1}{|c|}{ Name of the Element } & Quantity \\
\hline Objects of innovation infrastructure & $\mathbf{5 3 7}$ \\
\hline Business incubator & 73 \\
\hline Industrial park & 41 \\
\hline Innocenter & 3 \\
\hline Cluster & 140 \\
\hline Consortium & 3 \\
\hline Nanocenter & 11 \\
\hline Science park & 13 \\
\hline Special economic zone & 42 \\
\hline Area of advanced social and economic development (AAD) & 115 \\
\hline Technological platform & 5 \\
\hline Technology park & 91 \\
\hline Entities of innovation activity & $\mathbf{3 2 8 2}$ \\
\hline Leading universities & 72 \\
\hline Research centres & 136 \\
\hline Other institutions & 3074 \\
\hline World-class scientific and educational centers & $\mathbf{3 2}$ \\
\hline Total & $\mathbf{3 8 5 1}$ \\
\hline
\end{tabular}

Source: [18]

\section{DISCUSSION}

Thus, our conviction is that it is advisable to understand the innovation infrastructure as a set of companies that provide diverse assistance to the main participants in the organization of scientific and technological development (research organizations and industrial enterprises) with the creation and commercialization of innovations. This definition specifies the special intended purpose and place of the entities of this category of participants in the innovation process in the innovation ecosystem of industry. Accordingly, the methods of optimizing their activities to a certain extent should have specifics that are not characteristic of industrial enterprises and scientific organizations, but characteristic of the non-industrial sphere - the service sector. These are methods of network business organization, in which a scientific and methodological center with advanced practice stands out among the innovation infrastructure entities, and outsiders of the certification, consulting, recreation markets and other types of business serving innovators enter into junior partner relations with this leader. As an analogy, it can be recalled that the All-Union Classifier of National Economy Sectors (OKONKh), which existed until 2003, contained a special heading 95000 "Science and Scientific
Services". However, the forms of innovation infrastructure considered in the article were in fact absent.

\section{CONCLUSION}

Conducting international comparisons in the field of the organization of scientific and technological development allows us to conclude that one of the reasons for the lack of significant achievements in innovation activity in Russian conditions is the insufficient level of the development of innovation infrastructure or, in foreign terminology, "services" for startups and innovative companies as components of the innovation ecosystem. Moreover, the lag is observed not only in quantitative parameters but also as the organization of the activities of companies intended to ensure the process of creating and mastering product, process, organizational, and marketing innovations.

The conclusions obtained as a result of the study on the specifics of approaches to the organization of work on the development of innovation infrastructure entities form the practical basis for the start of a large-scale reform of this highly demanded business. It is advisable to concentrate further research on this issue in the direction of 
algorithmization of transformations in various areas of innovation support in industry.

\section{AUTHORS' CONTRIBUTIONS}

The study has been completed by a team of 5 authors. Artur D. Bobryshev has proposed the general idea of the work and conducted a study of statistics on the topic of the paper. Valeriy $\mathrm{M}$. Tumin, Elena E. Alenina, and Vladimir A. Trifonov have analyzed the positions of various authors on the issue under study. Andrei V. Savelyev has prepared methodological recommendations arising from the analysis of the definition and state of innovation infrastructure.

\section{REFERENCES}

[1] "Science, technology, innovation. Innovative development in Russia and EU countries. Express Info" [Nauka, tekhnologii, innovacii. Innovacionnoe razvitie $\mathrm{v}$ Rossii $\mathrm{i}$ stranah ES. Ekspress-informaciya], Moscow: ISIIEZ HSE, 2019, P. 2. (In Russ.).

[2] "Indicators of Innovation in the Russian Federation: 2020: Data Book", In Ed. by L. Gokhberg, K. Ditkovskiy, E. Evnevich, National Research University Higher School of Economics, Moscow: HSE, 2020, p. 336. (In Russ.). DOI: 10.17323/978-5-7598-2185-4

[3] "Science and innovation" [Nauka i innovacii]. Official website of the Federal State Statistics Service. (In Russ.). Retrieved from https://rosstat.gov.ru/folder/14477

[4] I. Alnafrah, "Efficiency evaluation of BRICS's national innovation systems based on biascorrected network data envelopment analysis", Journal of Innovation and Entrepreneurship, 2021, vol. 10(26). DOI: 10.1186/s13731-02100159-3

[5] S.I. Dovguchits, A.D. Bobryshev, "Upgrade of Russian industrial corporations in the conditions of establishing a national ecosystem", International Journal of Recent Technology and Engineering, 2019, vol. 8(3), pp. 6701-6705. DOI: 10.35940/ijrte.C6577.098319

[6] M. Parry, "Science and Technology Parks and Universities - Facing the Next Industrial Revolution", Higher Education in the Arab World, 2020, pp. 109-140. DOI:10.1007/978-3030-37834-9_5

[7] A.D. Bobryshev, T.K. Usmanova, M.V.
Chekadanova, "Management of the innovation stage of the production cycle in electronics", Studies on Russian Economic Development, 2020, vol. 31(3), pp. 284-293. DOI: $10.1134 / \mathrm{S} 1075700720030041$

[8] N.I. Komkov, A.A. Lazarev, V.S. Romantsov, V.V. Sutyagin, "State and perspectives of development of domestic industrial companies", Studies on Russian Economic Development, 2020, vol. 31(2), pp. 212-222. DOI: $10.1134 /$ S1075700720020045

[9] D.I. Kokurin, K.N. Nazin, "Formation and realization of the infrastructure potential of the Russian economy" [Formirovanie i realizaciya infrastrukturnogo potenciala ekonomiki Rossii], Moscow: Translit, 2011, 336 p. (In Russ.).

[10] A.V. Raikhlina, "Formation and development of infrastructure of innovation activity", Economics, statistics and informatics, 2013, vol. 2, pp. 59-62. (In Russ.). DOI: 10.21686/25003925-2013-2-59-62

[11]T.V. Eferyna, V.O. Lizunova, D.V. Prosyanyuk, D.A. Shinova, "Innovative infrastructure as a factor of inter-regional differentiation in the Russian Federation", Public Administration Issues, 2017, vol. 1, pp. 191-212. (In Russ.).

[12]I. Dezhina, "Innovation policy in Russia and the development of university-industry linkages", Industry and Higher Education, 2018, vol. 32(4), pp. 245-252. DOI: $10.1177 / 0950422218774974$

[13] Cornell University, INSEAD, and WIPO. The Global Innovation Index 2020: Who Will Finance Innovation? Ithaca, Fontainebleau, and Geneva, 2020.

[14] K.G. Hobbs, A.N. Link, J.T. Scott, "Science and technology parks: An annotated and analytical literature review", The Journal of Technology Transfer, 2017, vol. 42(4), pp. 957-976. DOI: 10.1007/s10961-016-9522-3

[15] "Business model generation: a handbook for visionaries, game changers, and challengers", Chichester: Wiley, 2010, 281 p.

[16] J.M. Pique, "Areas of innovation in a global world: Concept and practice", Malaga: IASP, 2016, 253 p.

[17] OECD/Eurostat, Oslo Manual 2018: Guidelines for Collecting, Reporting and Using Data on Innovation, 4th Edition, The Measurement of Scientific, Technological and Innovation 
Activities, OECD Publishing, Paris/Eurostat, Luxembourg, 2018. Retrieved from https://doi.org/10.1787/9789264304604-en

[18] "Innovation infrastructure and main indicators of innovation activity of the constituent entities of the Russian Federation" ["Innovacionnaya infrastruktura i osnovnye pokazateli innovacionnoj deyatel'nosti sub"ektov Rossijskoj Federacii”]. Official website of the Ministry of Science and Higher Education of the Russian Federation. (In Russ.). Retrieved from https://www.miiris.ru/inno_infra 